\title{
SEBARAN LUTUNG Trachypithecus cristatus (Raffles, 1821) DI PULAU PAHAWANG, INDONESIA
}

\author{
Distribution of Lutung Trachypithecus cristatus (Raffles, 1821) in Pahawang Island, \\ Indonesia
}

\author{
Putri Wahyuni, Indra Gumay Febryano, Dian Iswandaru, Bainah Sari Dewi \\ Jurusan Kehutanan, Fakultas Pertanian, Universitas Lampung \\ Jln, Prof. Dr. Soemantri Brojonegoro No. 1 Gedung Meneng, Bandar Lampung \\ *Email: putriwahyuni0898@gmail.com
}

Direvisi: 05/06/2020, Diterbitkan: 01/08/2020

\begin{abstract}
Human and wildlife conflicts have a negative impact, especially langurs whose habitat in a small island. The study objective was to identify presence and the distribution of langurs in a small island. Data were collected using observation methods, then analyzed using descriptive analysis. The results show that there were 23 langur groups that distributed in 23 locations, with the number of smallest groups consisting of 6 individuals and the number of largest groups consisting of 12 individuals. Langur was found in the morning at 05.38 WIB10.57 WIB and in the afternoon at 17.08 WIB-18.10 WIB. Most of these animals are found in agroforestry areas and a small part in mangrove forests. The highest activity intensity is found in the morning with the form of eating, locomotion (moving), grooming and resting activities. The existence of langurs in a small island is a good thing and must be preserved because langurs belong to protected animals. One way to conserve these animals is to create alternative conservation-based langur tourism.
\end{abstract}

Keywords; Small island, langur, human and animal conflict.

\section{ABSTRAK}

Konflik manusia dan satwa liar berdampak negatif khususnya lutung yang habitatnya berada di pulau kecil. Tujuan penelitian ini untuk mengidentifikasi keberadaan dan sebaran lutung di pulau kecil. Data dikumpulkan menggunakan metode observasi, kemudian dianalisis menggunakan analisis deskriptif. Hasil penelitian menunjukkan bahwa ada 23 kelompok lutung yang tersebar di 23 lokasi, dengan jumlah kelompok terkecil terdiri dari 6 ekor dan jumlah kelompok terbesar terdiri dari 12 ekor. Lutung ditemukan pada pagi hari pukul 05.3810.57 WIB dan sore hari pukul 17.08-18.10 WIB. Sebagian besar satwa ini ditemukan di kawasan agroforestri dan sebagian kecil di hutan mangrove. Intensitas aktivitas tertinggi ditemukan pada pagi hari yaitu makan, lokomosi (berpindah tempat), grooming dan istirahat. Keberadaan lutung di pulau kecil merupakan hal positif, sehingga harus dilestarikan karena lutung tergolong satwa yang dilindungi. Salah satu cara melestarikan satwa tersebut adalah membuat wisata lutung berbasis konservasi.

Kata kunci; Pulau kecil, lutung, konflik satwa dan manusia.

\section{PENDAHULUAN}

Konflik manusia dan satwa liar mengakibatkan fragmentasi habitat (Baskaran et al., 2013), perambahan habitat dari faktor eksternal, perburuan, ekstraksi sumber daya hutan dan degradasi lahan (Karanth \& DeFries, 2010). Munculnya konfilik pada kondisi tertentu dapat merugikan kedua belah pihak, baik satwa maupun manusia (Rianti dan Garsetiasih, 2017; Sembiring et al., 2016; Iswandaru et al., 2020). Berdasarkan Peraturan Menteri 
Kehutanan Nomor P.48/Menhut-II/2008 tentang Pedoman Penanggulangan Konflik antara Manusia dan Satwa Liar, menjelaskan bahwa konflik manusia dan satwa liar terjadi akibat sejumlah interaksi negatif baik langsung maupun tidak langsung antara manusia dan satwa liar. Hal ini memicu pembunuhan pembalasan dan menyebabkan beberapa spesies satwa liar terancam punah (Liu et al., 2010) salah satunya yaitu lutung (Trachypithecus cristatus).

Lutung merupakan salah satu satwa liar yang dilindungi menurut Peraturan Menteri Lingkungan Hidup dan Kehutanan Nomor 106 tahun 2018. Satwa liar ini memiliki sebaran mulai dari daratan Asia Tenggara hingga wilayah Sunda (Roos et al., 2008), semenanjung Melayu dan kepulauan serta tergolong ke dalam primata arboreal (Amarasinghe et al., 2009). Habitat utama satwa tersebut di alam liar di antaranya hutan hujan (Wirdateti et al., 2009), hutan bakau, hutan yang berdekatan dengan sungai maupun lahan pertanian atau agroforestri, serta daerah pesisir (Hambali et al., 2016).

Aktivitas manusia yang cenderung merusak ekosistem (Isman et al., 2019; Akbar, 2017; Suherli et al., 2016) akan menyebabkan keberadaan lutung terancam karena berkurangnya habitat, serta mengakibatkan sebaran satwa yang terbatas (Nijman \& Meijaard, 2008). Salah satu habitat satwa ini berada di pulau-pulau kecil yang merupakan ekosistem yang rentan terhadap perubahan lingkungan (Cherian, 2007; Zulrizkan et al., 2018). Hal tersebut dipengaruhi oleh faktor-faktor keterbatasan sumber daya alam dan isolasi. Oleh karena itu, penelitian ini bertujuan untuk mengidentifikasi sebaran lutung yang berada di Pulau Pahawang agar keberadaannya dapat dilestarikan. Sebagaimana menurut Mardani et al. (2017) Pulau Pahawang merupakan bagian dari pulau-pulau kecil di kawasan Teluk Lampung yang terdiri dari laut, pantai, rawa, daratan dan daerah perbukitan.

\section{METODE}

Penelitian dilakukan di Pulau Pahawang, Kecamatan Marga Punduh, Kabupaten Pesawaran, Provinsi Lampung (Gambar 1) pada bulan November sampai Desember 2019. Alat yang digunakan yaitu kamera digital, GPS, binokuler dan kuesioner, serta objek penelitiannya berupa satwa lutung. Pengumpulan data menggunakan metode observasi pada pagi hari pukul 05.00 WIB hingga sore pukul 18.30 WIB. Data yang dikumpulkan meliputi titik keberadaan lutung, jumlah kelompok lutung, jumlah individu setiap kelompok dan aktivitas lutung. Analisis deskriptif digunakan untuk menggambarkan keberadaan dan sebaran lutung serta kondisi habitatnya.

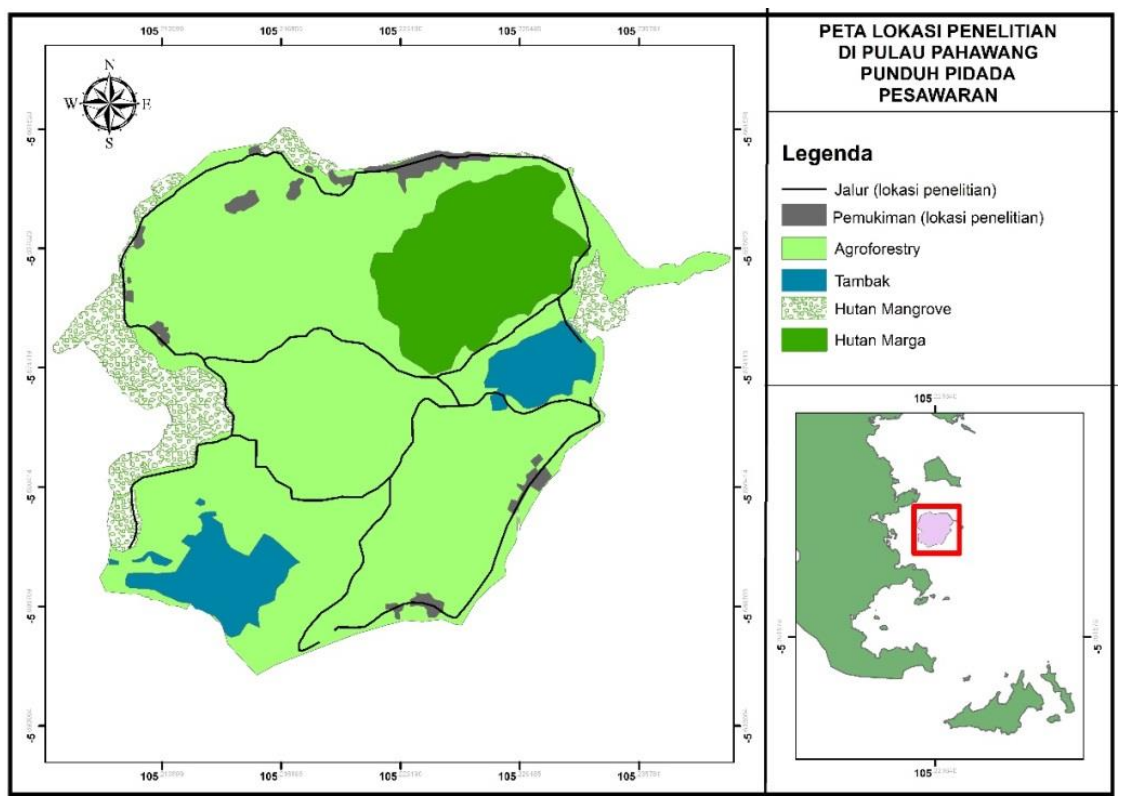

Gambar 1. Peta lokasi penelitian.

Figure 1. Map of research location. 


\section{HASIL DAN PEMBAHASAN}

\section{A. Kondisi Lokasi Penelitian}

Pulau Pahawang terletak di Kecamatan Marga Punduh, Kabupaten Pesawaran, Provinsi Lampung, Indonesia. Pulau ini terbagi menjadi dua yaitu Pahawang Besar dan Pahawang Kecil, memiliki luas sekitar 1.084 hektar (Jainah dan Marpaung, 2017).

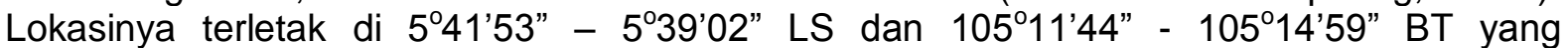
berdekatan dengan Teluk Punduh Pidada (Hakim et al., 2017). Adanya sumber daya tarik wisata unggulan menjadikan Pulau Pahawang tergolong Kawasan Strategi Pariwisata Daerah (KSPD) (Alvi et al., 2018).

Karakteristik tutupan lahan di Pulau Pahawang meliputi pemukiman, agroforestri, hutan mangrove, hutan marga dan tambak. Luas pemukiman di pulau ini sekitar $15 \mathrm{Ha}$ dan dibagi menjadi enam dusun, diantaranya dusun Suak Buah, Penggetahan, Jeralangan, Kalangan, Pahawang dan Cukuh Nya'i. Luas tutupan lahan agroforestri sebesar 830,86 Ha, dengan kompoisi tanaman antaralain kakao, kelapa, cengkeh, durian, rambutan, dukuh, sukun, petai, mangga, pinang, jengkol dan aren. Luas hutan mangrove sebesar 141,94 Ha. Hutan marga terletak di perbukitan yang sekaligus berfungsi sebagai buffer zone di Pulau Pahawang. Lahan agroforestri dan hutan mangrove letaknya tidak berjauhan dan hanya dipisahkan jalan setapak.

Saat ini Pulau Pahawang sedang melakukan pengembangan pariwisata berkelanjutan (Nurhasanah et al., 2017; Febryano, 2017). Fokus pengembangan destinasi wisatanya ditujukan untuk konservasi dengan destinasi wisata terutama terumbu karang dan konservasi mangrove (Muliarto et al., 2017; Febryano et al., 2012). Menurut Dinas Pariwisata dan Ekonomi Kreatif Provinsi Lampung (2014) wisatawan pada tahun 2010 hingga 2014 mengalami peningkatan.

\section{B. Keberadaan Lutung di Pulau Pahawang}

Keberadaan lutung tersebar di 23 titik lokasi dengan 23 kelompok (Tabel 1) yang masing-masing kelompok memiliki jumlah individu berbeda. Jumlah individu pada tiap kelompok lutung yang ditemukan rata-rata mulai dari 6 ekor hingga 12 ekor. Menurut IUCN (2015) kelompok lutung memiliki jumlah individu rata-rata terkecil 7 hingga 8 ekor di setiap kelompoknya.

Tabel 1. Sebaran Lutung (Trachypithecus cristatus) di Pulau Pahawang Table 1. Distribution of Lutung (Trachypithecus cristatus) in Pahawang island

\begin{tabular}{ccccc}
\hline $\begin{array}{c}\text { Kelompok } \\
\text { Lutung }\end{array}$ & Waktu & $\mathrm{X}$ & $\mathrm{Y}$ & $\begin{array}{c}\text { Jumlah } \\
\text { (Ekor) }\end{array}$ \\
\hline 1 & 05.38 & 105,21284 & $-5,6734584$ & 9 \\
2 & 05.40 & 105,21036 & $-5,6717417$ & 7 \\
3 & 05.44 & 105,21092 & $-5,6728317$ & 6 \\
4 & 05.49 & 105,21626 & $-5,6732883$ & 8 \\
5 & 05.53 & 105,21705 & $-5,6728750$ & 7 \\
6 & 05.53 & 105,21003 & $-5,6721783$ & 7 \\
7 & 06.07 & 105,23207 & $-5,6703033$ & 7 \\
8 & 06.15 & 105,22735 & $-5,6733917$ & 9 \\
9 & 06.24 & 105,21760 & $-5,6635850$ & 12 \\
10 & 06.54 & 105,21347 & $-5,6635918$ & 10 \\
11 & 06.57 & 105,20969 & $-5,6716571$ & 7 \\
12 & 10.57 & 105,21003 & $-5,6721780$ & 6 \\
13 & 16.50 & 105,21157 & $-5,6733103$ & 6 \\
14 & 17.08 & 105,21267 & $-5,6788549$ & 8 \\
15 & 17.13 & 105,20859 & $-5,6698118$ & 8 \\
16 & 17.25 & 105,20884 & $-5,6688570$ & 12 \\
17 & 17.30 & 105,21142 & $-5,6795532$ & 8
\end{tabular}




\begin{tabular}{lllll}
18 & 17.35 & 105,21182 & $-5,6793761$ & 9 \\
19 & 17.44 & 105,21732 & $-5,6725936$ & 10 \\
20 & 17.45 & 105,21040 & $-5,6717830$ & 7 \\
21 & 17.55 & 105,20886 & $-5,6689750$ & 8 \\
22 & 18.08 & 105,20802 & $-5,6690860$ & 6 \\
23 & 18.10 & 105,21805 & $-5,6637152$ & 7 \\
\hline
\end{tabular}

Sumber: Data Primer (2019).

Kelompok lutung dengan jumlah individu terkecil yaitu 6 ekor ditemukan pada kelompok 3; 12; 13; dan 22, sedangkan kelompok terbanyak yaitu 12 ekor pada kelompok 9 dan 16 . Masing-masing kelompok dapat dijumpai mulai dari pagi hari hingga sore hari pada pukul 05.38 WIB hingga 18.10 WIB. Kelompok yang terlihat di pagi hari yaitu kelompok $1 ; 2 ; 3 ; 4 ; 5 ; 6 ; 7 ; 8 ; 9 ; 10 ; 11$ dan 12, sedangkan pada saat sore yaitu $13 ; 14 ; 15 ; 16 ; 17 ; 18 ; 19 ; 20 ; 21 ; 22$ dan 23. Waktu ditemukannya satwa ini pada pagi hari yaitu pukul 05.38 WIB hingga 10.57 WIB, sedangkan sore ditemukan pukul 16.50 WIB hingga 18.10 WIB. Jumlah yang ditemukan saat pagi yaitu 95 ekor, sedangkan sore 89 ekor. Total akumulasi keseluruhan satwa yang ditemukan yaitu 184 ekor. Sebaran lutung di pulau ini sebagian besar dapat ditemukan di kawasan agroforestri dan sebagian kecil ditemukan di hutan mangrove (Gambar 2). Sejalan dengan penelitian Hambali et al. (2016) bahwa habitat utama lutung berada di hutan bakau atau mangrove, bahkan lahan pertanian atau agroforestri serta hutan yang berdekatan dengan sungai atau sempadan sungai.

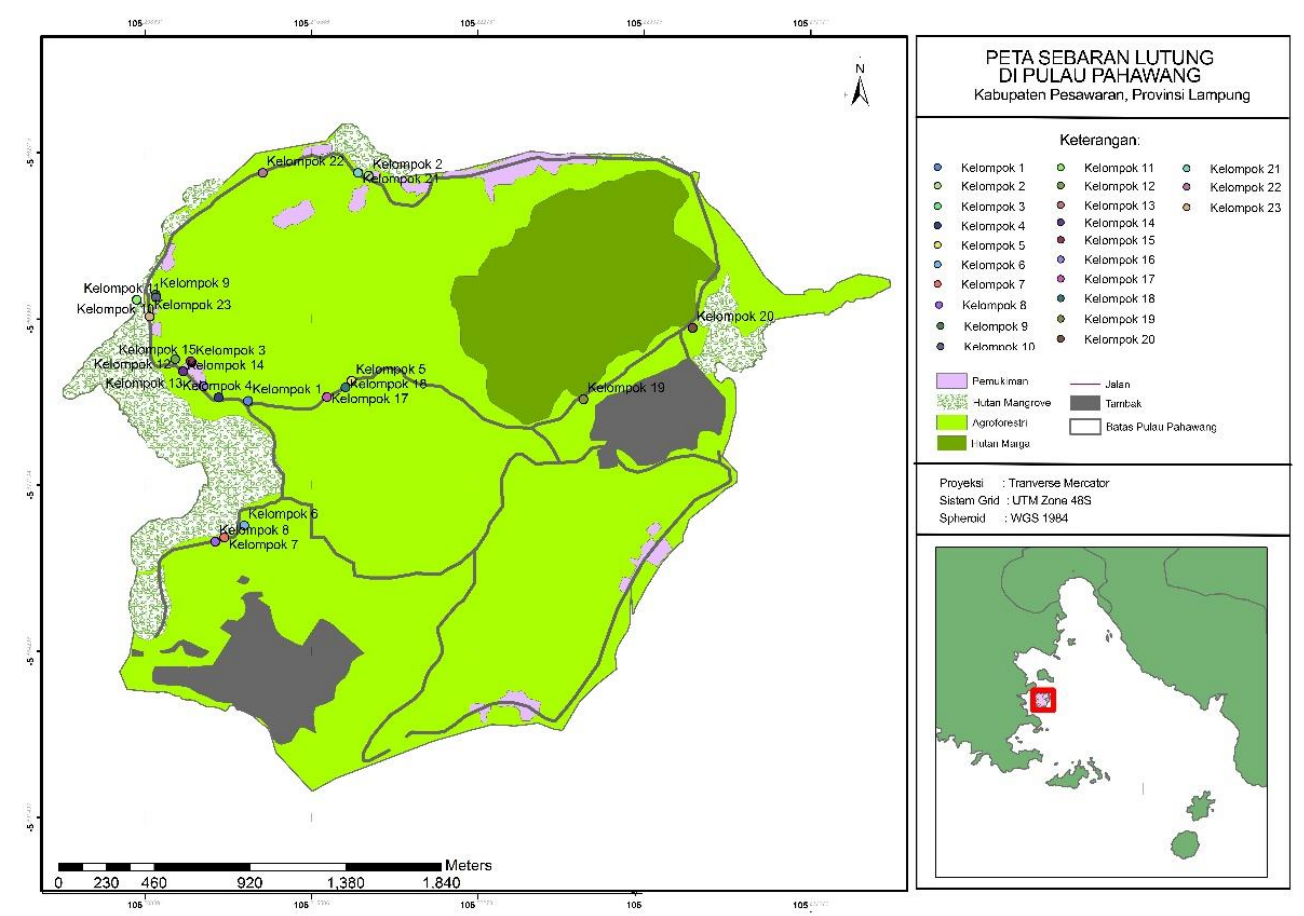

Gambar 2. Peta sebaran lutung (Trachypithecus cristatus) di Pulau Pahawang. Figure 2. Map of Lutung (Trachypithecus cristatus) distribution in Pahawang Island.

Bentuk aktivitas satwa lutung meliputi makan, lokomosi, grooming (membersihkan diri) dan istirahat. Sontono et al. (2016) menyatakan bahwa mulai pukul 05.30 WIB lutung mengawali aktivitasnya di pagi hari. Hal ini juga ditegaskan Sulistyadi et al. (2013) bahwa intensitas aktivitas lutung tertinggi dilakukan pada pagi hari dibandingkan dengan sore hari.

Makan merupakan bentuk aktivitas yang tidak bisa ditinggalkan oleh lutung. Sebesar $95 \%$ satwa ini mencari kebutuhan pakannya di kawasan agroforestri, sedangkan hanya $0,5 \%$ di hutan mangrove. Fenomena ini terjadi karena kawasan agroforestri menyediakan sumber pakan sepanjang tahun, sedangkan hutan mangrove tidak. Tanaman yang biasanya dimakan satwa tersebut berupa pucuk atau daun muda, bunga dari tanaman 
berbuah dan sebagian kecil buah-buahan. Hal ini sejalan dengan studi Amarasinghe et al. (2009) bahwa primata arboreal seperti lutung termasuk satwa pemakan tumbuh-tumbuhan. Lebih lanjut, Eliana et al. (2017) menyatakan bahwa lutung lebih menyukai daun muda dibandingkan dengan buah-buahan.

Jenis tanaman yang menjadi sasaran lutung di kawasan agroforestri antara lain durian (Durio zibethinus), pinang (Areca catechu), mangga (Mangifera indica), dukuh (Lansium domesticum), rambutan (Nephelium lappaceum), petai (Parkia speciosa), jengkol (Archidendron pauciflorum), kelapa (Cocos nucifera) dan cengkeh (Syzigium aromaticum). Satwa ini juga memakan pucuk mangrove atau daun muda dari berbagai jenis mangrove yang ada. Menurut penelitian Salampessy et al. (2012); Salampessy et al. (2017); Mulyana et al. (2018) agroforestri merupakan bentuk pemanfaatan lahan dengan pola tanam yang terdiri dari tanaman berkayu dan tanaman pertanian. Jumlah pakan yang melimpah dengan komponen tanaman berkayu dan tanaman pertanian di kawasan agroforestri menjadikan lutung lebih tertarik dibanding hutan mangrove yang minim ketersediaan pakan. Ayunin et al. (2014) menyatakan bahwa karakteristik habitat seperti intensitas manusia dan jarak dari gangguan merupakan faktor penentu keamanan lutung dalam mencari makan.

Tingkah laku lutung mencari makan dapat ditemukan di strata tajuk pohon terendah, sedang hingga tertinggi. Menurut penelitian Ihsanu et al. (2013) satwa ini ditemukan di strata tajuk terendah dengan ketinggian 0-5 meter, kemudian pada strata tajuk sedang di ketinggian 6-15 meter dan strata tajuk tertinggi di ketinggian pohon $>15$ meter. Posisi makan lutung yang ditemukan yaitu duduk, berdiri dan bergelantungan. Posisi berdiri hanya dilakukan oleh jantan dewasa. Studi Eliana et al. (2017) menyatakan bahwa perilaku makan lutung jantan dengan posisi berdiri dilakukan untuk pengawasan dan perlindungan pada kelompoknya saat ada kompetitor.

Pola perilaku lutung mengambil pakan biasanya menggunakan tangan kiri maupun kanan atau langsung menggunakan mulut (Gambar 3). Satwa ini juga kadang menggunakan kaki untuk mengambil makanan. Kedua tangannya biasanya digunakan untuk memakan buah-buahan. Giginya yang tajam digunakan untuk menyobek jenis pakan yang terlalu keras sehingga bisa memudahkannya untuk mengunyah.

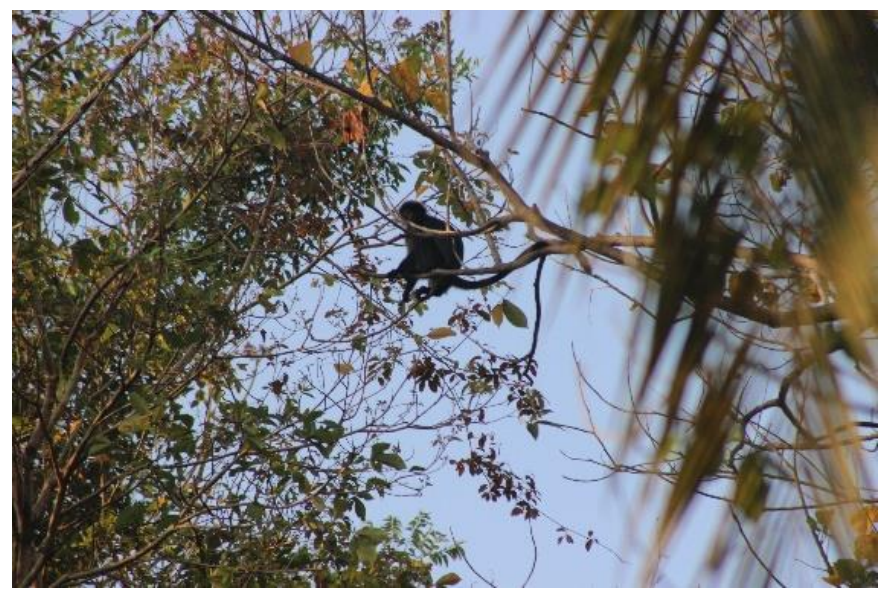

Gambar 3. Aktivitas makan lutung (Trachypithecus cristatus) di pohon rambutan.

Figure 3. Eating langur (Trachypithecus cristatus) activity in rambutan trees.

Lutung melakukan aktivitas berpindah, biasanya dilakukan dari satu pohon ke pohon lainnya, kemudian melompat, mengayunkan tubuhnya ke ranting pohon, sehingga tangan dan kakinya akan mencengkram ranting lainnya. Menurut Sontono et al. (2016) perilaku berpindah tempat dari pohon tempat beristirahat ke pohon lainnya dinamakan lokomosi. Biasanya lokomosi dilakukan seiring dengan satwa ini mencari makan, atau bergerak mengitari home range, berpindah dari strata kanopi pohon terendah, sedang hingga tertinggi. Supriatna dan Ramadhan (2016) menyatakan bahwa lutung tergolong presbytis yang biasa hidup di atas pohon (arboreal) dan aktif pada siang hari (diurnal). 
Aktivitas grooming ditemukan pada pagi hari dan sore hari. Aktivitas ini merupakan pola perilaku sosial yang terjadi antaran induk dengan anaknya, atau induk satu dengan induk lainnya. Biasanya kegiatan yang dilakukan yaitu menyisik badan atau mencari kutu. Menurut Indriyati et al. (2017), grooming merupakan aktivitas membersihkan diri atau membersihkan individu lain yang sudah menjadi bentuk rutinitas sosial satwa tersebut. Sejalan dengan pendapat Ahmadi et al. (2016) grooming adalah aktivitas berkutu yang bertujuan membersihkan diri dari kotoran dan parasit yang dilakukan secara individu maupun kelompok.

Istirahat merupakan salah satu bentuk aktivitas yang dimiliki lutung. Satwa ini mulai tidak terlihat pada pukul 11.00 WIB hingga pukul $15.30 \mathrm{WIB}$, waktu tersebut diduga memungkinkan satwa untuk beristirahat dari bentuk aktivitas mencari makan, grooming dan lokomosi. Subagyo et al. (2008) menjelaskan bahwa istirahat adalah bentuk aktivitas lutung tanpa melakukan perpindahan tempat dari satu pohon ke pohon lainnya. Istirahat merupakan kebutuhan satwa untuk tetap menjaga kondisi tubuhnya.

\section{KESIMPULAN DAN SARAN}

Keberadaan lutung yang teridentifikasi berjumlah 23 kelompok di 23 titik lokasi. Jumlah kelompok terkecil terdiri dari 6 ekor lutung dan jumlah kelompok terbesar terdiri dari 12 ekor lutung. Lutung ditemukan mulai pukul 05.38 WIB di pagi hari hingga 18.10 WIB di sore hari. Satwa ini sebagian besar ditemukan di kawasan agroforestri dan hanya sebagian kecil di hutan mangrove. Intensitas aktivitas tertinggi ditemukan pada saat pagi hari dengan bentuk aktivitas makan, lokomosi (berpindah tempat), grooming dan istirahat. Keberadaan lutung di pulau ini perlu dilestarikan mengingat satwa tersebut terancam kepunahannya.

\section{DAFTAR PUSTAKA}

Ahmadi, E.S., Oktorini, Y. \& Yoza, D. (2016). Identifikasi daerah jelajah beruk (Macaca nemestrina linnaeus, 1766) menggunakan aplikasi Sistem Informasi Geografis di kawasan hutan Universitas Riau. Jurnal Jom Faperta UR, 3(2), 1-12.

Akbar, N., Haya, N., Baksir, A., Harahap, Z.A., Tahir, I., Ramili, Y. \& Kotta, R. (2017). Struktur komunitas dan pemetaan ekosistem mangrove di Pesisir Pulau Maitara, Provinsi Maluku Utara, Indonesia. Jurnal IImu-IImu Perairan. Pesisir dan Perikanan, 6(2), 167-181.

Alvi, N.N., Nurhasanah, I.S. \& Persada, C. (2018). Evaluasi keberlanjutan wisata bahari Pulau Pahawang Kabupaten Pesawaran. Plano Madani, 7, 59-68.

Amarasinghe, A.A.T., Botejue, W., Madhava, S. \& Harding, L.E. (2009). Social behaviours of captive Trachypithecus cristatus (Mammalia: Cercopithecidae) in the National Zoological Gardens of Sri Lanka. Journal Taprobanica, 1, 66-73.

Amin, A.M., Irawat, M.H., Rohman, F. \& Syamsuri, I. (2016). Sosialisasi pengelolaan hutan mangrove berkelanjutan sebagai upaya peningkatan kesadaran siswa dan masyarakat akan dampak alih fungsi lahan mangrove (Studi kasus di Kecamatan Bangkala Kabupaten Jeneponto Sulawesi Selatan). Prosiding Seminar Nasional Biologi, 330338.

Ayunin, Q., Pudyatmoko, S. \& Imron, M.A. (2014). Seleksi habitat lutung jawa (Trachypithecus auratus E. Geoffroy Saint-Hilaire, 1812) di Taman Nasional Gunung Merapi. Jurnal Penelitian Hutan dan Konservasi Alam, 11(3), 261-279.

Baskaran, N., Kannan, G., Anbarasan, U., Thapa, A. \& Sukumar, R. (2013). A landscapelevel assessment of asian elephant habitat, its population and elephant-human conflict in the Anamalai Hill Ranges of Southern Western Ghats, India. Mammalian Biology, 78(6), 470-481. 
Cherian, A. (2007). Linkages between biodiversity conservation and global climate change in Small Island Developing States (SIDS). Natural Resources Forum, 31(2), 128-131.

CITES. (2017). The Convention on International Trade in Endangered Species of Wild Fauna and Flora. Washington, D.C.: CITES.

Davinsy, R., Kustanti, A., \& Hilmanto, R. (2015). Kajian pengelolaan hutan mangrove di Desa Pulau Pahawang Kecamatan Marga Punduh Kabupaten Pesawaran. Jurnal Sylva Lestari, 3(3), 95-106.

Dinas Pariwisata dan Ekonomi Kreatif Provinsi Lampung. (2014). Perkembangan Pariwisata Lampung Tahun 2014. Bandar Lampung: Dinas Pariwisata dan Ekonomi Kreatif Provinsi Lampung.

Eliana, D., Nasution, E.K. \& Indarmawan. (2017). Tingkah laku makan lutung jawa Trachypithecus auratus di Kawasan Pancuran 7 Baturaden Gunung Slamet Jawa Tengah. Scripta Biologica, 4(2), 125-129.

Febryano, I. G. (2014). Politik Ekologi Pengelolaan Mangrove di Kabupaten Pesawaran Provinsi Lampung. [Disertasi]. Bogor: Institut Pertanian Bogor.

Febryano, I. G., Sinurat, J. \& Salampessy, M. L. (2017). Social relation between businessman and community in management of intensive shrimp pond. Earth and Environmental Science, 55(1), 1-7.

Hakim, L., Lazuardi, W., Astuty, I.S., Hadi, A.A., Hermayani, R., Noviandias, D. \& Dewi, A.C. (2017). Assessing Worldview-2 Satellite imagery accuracy for bathymetry mapping in Pahawang Island, Lampung, Indonesia. Earth and Environmental Science, 165(1), 1-8.

Hambali, K., Md-Zain, B.M. \& Amir, A. (2016). Daily movement, sleeping sites and canopy level use of habituated silvered-leaf monkeys (Trachypithecus cristatus) in Bukit Malawati, Kuala Selangor, Malaysia. Journal of Sustainability Science and Management, 11(2), 21-30.

Ihsanu, I.A., Setiawan, A. \& Rustiati, E.L. (2013). Studi perilaku makan dan analisis vegetasi pakan lutung jawa (Trachypithecus auratus) di Taman Nasional Gunung Ciremai. Jurnal Sylva Lestari, 1(1), 17-22.

Indriyati, E., Nugroho, A.S. \& Kaswinarni, F. (2017). Bentuk interaksi intraspesifik lutung budeng (Trachypithecus auratus) di Kawasan Hutan Adinuso Kecamatan Subah Kabupaten Batang. Jurnal Bioma, 6(1), 1-13.

Isman, M., Rani, C., Haris, A. \& Faizal, A. (2019). Sebaran dan kondisi ekosistem perairan di Pulau Panampeang Polewali Mandar. Jurnal Ilmu Kelautan, 5(1), 16-20.

Iswandaru, D., Pratiwi, P., Rahayu, P.S., Rizaldi, A. \& Winarno, G.D. (2020). Persepsi masyarakat terhadap konflik manusia dan gajah sumatra (Elephas maximus sumatranus Temminck 1847) di Taman Nasional Way Kambas. Jurnal Sylva Lestari, 8(1), 98-108.

IUCN. (2015). International Union for Conservation of Nature and Natural Resources. http://dx.doi.org/10. 2305/IUCN. UK. 2008. RLTS. T22035A9348474. en. Diakses 8 April 2019.

Jainah, Z.O. \& Marpaung, L.A. (2017). Pelaksanaan kearifan lokal di kawasan wisata Pulau Pahawang, Kabupaten Pesawaran, Propinsi Lampung. Jurnal IImu Hukum, 8, 40-44.

Karanth, K.K. \& DeFries, R. (2010). Conservation and management in human-dominated landscapes: Case studies from India. Biological Conservation, 143, 2865-2869.

Liu, F., McShea, W.J., Garshelis, D.L., Zhu, X., Wang, D. \& Shao, L. (2010). Human-wildlife conflicts influence attitudes but not necessarily behaviors: Factors driving the poaching of bears in China. Biological Conservation, 144, 538-547.

Mardani, A., Purwanti, F. \& Rudiyanti, S. (2017). Strategi pengembangan ekowisata berbasis masyarakat di Pulau Pahawang Propinsi Lampung. Journal of Maquares, 6(1), 1-9.

Mulyana, L., Febryano, I.G., Safe'i. R. \& Banuwa, I.S. (2018). Performa pengelolaan agroforestri di wilayah Kesatuan Pengelolaan Hutan Lindung Rajabasa. Jurnal Hutan Tropis, 5(2), 127-133. 
Nijman, V., Meijaard, E. (2015). Trachypithecus cristatus. The IUCN Red List of Threatened Species 2008: e. T22035A9348474. http://dx.doi.org/10.2305/IUCN. UK. 2008. RLTS. T22035A9348474. en. Diakses 8 April 2019.

Nugroho, A.A. \& Sugiyarto. (2015). Kajian perilaku kera ekor panjang (Macaca fascicularis) dan lutung (Trachypithecus auratus) di Coban Rondo, Kabupaten Malang. Jurnal IImiah Biologi, 3, 33-38.

Rianti, A., \& Garsetiasih, R. (2017). Persepsi masyarakat terhadap gangguan gajah sumatera (Elephas maximus sumatranus) di Kabupaten Ogan Komering Ilir. Jurnal Penelitian Sosial dan Ekonomi Kehutanan, 14(2), 83-99.

Roos, C., Nadler, T. \& Walter, L. (2008). Mitochondrial phylogeny, taxonomy and biogeography of the silvered langur species group (Trachypithecus cristatus). Molecular Phylogenetics and Evolution, 47, 629-636.

Salampessy, M.L., Bone, I. \& Febryano, I.G. (2012). Performansi dusung pala sebagai salah satu agroforestri tradisional di Maluku. Jurnal Tengkawang, 2(2), 55-65.

Salampessy, M.L., Febryano, I.G. \& Zulfiani, D. (2017). Bound by debt: Nutmeg trees and changing relations between farmers and agents in a moluccan agroforestry systems. Forest and Society, 1(2), 137-143.

Sembiring, R.P., Setiawan, A. \& Darmawan, A. (2016). Penyebaran dan kelimpahan populasi monyet ekor panjang (Macaca fascicularis) di Cagar Alam Sibolangit, Jurnal Sylva Lestari, 4(3), 47-58.

Sontono, D., Widiana, A. dan Sukmaningrasa. S. (2016). Aktivitas harian lutung jawa (Trachypithecus auratus sondacius) di kawasan Taman Buru Masigit Kareumbi Jawa Barat. Jurnal Biodjati, 1(1), 39-47.

Subagyo, A., Arfan, E. \& Siburian, J. (2008). Pola aktivitas harian lutung (Presbytis cristata, Raffles 1821) di hutan sekitar Kampus Pinang Masak, Universitas Jambi. Jurnal Pendidikan Biologi, 1(1), 6-10.

Sulistiyadi, E., Kartono, A.P. \& Maryanto, I. (2013). Pergerakan lutung jawa Trachypithecus auratus (E. Geoffroy 1812) pada fragmen habitat terisolasi di Taman Wisata Alam Gunung Pancar (TWAGP) Bogor. Jurnal Berita Biologi, 12(3), 383-395.

Supriatna, J. \& Wahyono, E.H. (2000). Panduan Lapangan Primata Indonesia. Jakarta: Yayasan Obor Indonesia.

Suherli, D., Harianto, S.P. \& Widodo, Y. (2016). Kajian perilaku dan pakan drop in monyet hitam sulawesi (Macaca nigra) di Taman Agro Satwa dan Wisata Bumi Kedaton. Jurnal Sylva Lestari, 4(2), 1-8.

Wirdateti., Pratiwi, A.N., Diapari, D. \& Tjakradidjaja, A.S. (2009). Perilaku harian lutung (Trachypithecus cristatus, Raffles 1812) di Penangkaran Pusat Penyelamatan Satwa Gadog, Ciawi-Bogor. Jurnal Zoo Indonesia, 18, 33-40.

Yasuma, S. \& Alikodra, H.S. (1992). Mammal of Bukit Soeharto Protection Forest. The Tropical Forest Research Project Spesial Publication No.1 dan 2 Edition. Samarinda: Mulawarman University.

Zulrizkan, A.P., Hasibuan, H.S. \& Koestoer, R.H. (2018). Peran informasi geospasial dalam mendukung penataan ruang wilayah pulau-pulau kecil berbasis adaptasi perubahan iklim. Seminar Nasional Geomatika, 841-850. 